\author{
Olivia Kłusek
}

Uniwersytet Jagielloński

\title{
Prawda o kobiecie - feminizm i trywializacja w kobiecej prasie segmentu luksusowego w Polsce
}

\begin{abstract}
Streszczenie
Przedmiotem pracy jest problematyka trywializacji pojęcia feminizmu w mediach, a konkretnie w segmencie kobiecej prasy luksusowej. Punktem uyjścia poczynionych rozważań jest zjawisko negocjowania znaczenia feminizmu w mediach. Przeanalizowano, w jaki sposób dyskurs feministyczny (rozumiany jako sposób użycia języka) jest trywializowany u Polsce. Opisano przejawy postfeministycznego dyskursu w postaciach latte-feminizmu, pop-feminizmu i girl power oraz zuiązki pomiędzy nimi a konkretnym tytułem prasouym („Twój Styl”, „Wysokie Obcasy”, „Wysokie Obcasy Extra” i „Cosmopolitan”). Ponadto opracouano oryginalne, autorskie definicje form postfeminizmu, dotychczas niespotykane w pracach naukowych. Badania empiryczne oparto na analizie zawartości luksusouych czasopism kobiecych, która pokazała najważniejsze tendencje, uykorzystane w krytycznej analizie dyskursu.
\end{abstract}

Słowa kluczoue: feminizm, trywializacja feminizmu, girl power, pop-feminizm, latte-feminizm, analiza zawartości, krytyczna analiza dyskursu, magazyny kobiece segmentu luksusowego: „Twój Styl”, „Wysokie Obcasy”, „Wysokie Obcasy Extra”, „Cosmopolitan”.

\section{The truth about a woman - feminism and trivialisation in women's luxury press in Poland}

\begin{abstract}
The subject of the thesis is the issue of the trivialization of the concept of feminism in the segment of luxurious women's press. As a starting point the author adopted the phenomenon of negotiating the meaning of feminism in the media. The thesis was investigated at an angle of feminist discourse (understood as a way of using the language) trivialisation in Poland. The aim of this study was to describe the indications of post feminist discourse forms: latte-feminism, pop-feminism and girl power and to detect the connection between them and a particular press title ('Twój Styl', 'Wysokie Obcasy', 'Wysokie Obcasy Extra' and 'Cosmopolitan'). In the course of the thesis definitions of forms of post-feminism - previously unheard in academic work - were developed. The study was based on content analysis that showed the most important trends, used later to critical discourse analysis.
\end{abstract}

Key words: feminism, women's press, girl power, pop feminism, latte feminism, luxury magazines segment, content analysis, discourse analysis, 'Tuój Styl', 'Wysokie Obcasy Extra', 'Wysokie Obcasy', 'Cosmopolitan'. 


\section{Wprowadzenie}

Zbyszko Melosik w książce pt. Tożsamość, ciało i władza: teksty kulturowe jako (kon)teksty pedagogiczne, pisze, że „istnieje wiele feminizmów, z których każdy pragnie uzyskać status metanarracji - być tym jednym, jedynym, prawdziwym feminizmem; dostarczyć Praudę o kobiecie i możliwościach jej wyzwolenia”"1. Do niedawna głównym głosem polskich (i nie tylko) feministek był ten pogardliwie określany jako latte-feminizm na zmianę z dyskursem girl power - silnej, niezależnej, agresywnej kobiety. Dzisiaj do roli takiej metanarracji pretenduje kolejna odmiana - pop-feminizm.

Autorka, będąc stałą czytelniczką zarówno anglojęzycznej, jak i krajowej prasy kobiecej zaliczanej do segmentu luksusowego, zauważyła w niej nagły wzrost popularności idei związanych z feminizmem czy ruchem emancypacyjnym kobiet, który można wręcz określić jako trend na feminizm. Nie byłoby w tym zjawisku nic godnego zatrzymania się i przyjrzenia, gdyby nie kontekst, w jakim artykuły umieszczane $\mathrm{w}$ glossy magazines przedstawiają ruch kobiecy.

Podstawą znakomitej większości analizowanych tekstów na ten temat w prasie skierowanej do kobiet było podkreślanie konieczności poprawy wizerunku zarówno feministki, jak i feminizmu jako takiego. Rok 2014 przyniósł „ogólnoświatową” (czyli głównie anglosaską) kampanię Rebranding Feminism. Wyjątkowe grudniowe wydanie najpopularniejszego pisma o modzie dla kobiet na świecie - „Elle” - The Feminism Issue było ukoronowaniem kampanii. Do jego tworzenia zaproszono ponad duieście kobiet, a czytelniczki zachęcano do dołączenia i zmienienia świata. Magazyn zatrudnił trzy światowej sławy agencje reklamowe - Brave, Mother i Wieden+Kennedy do pracy z feministkami przy poprawie „marki” feminizmu w oczach kobiet na całym świecie. Celem było dopasowanie niepasującej, zdaniem magazynu, ideologii do upodobań nowoczesnych kobiet, między innymi przez działania w mediach społecznościowych, w tym pokazywanie gwiazd, „prawdziwych kobiet-feministek” i znanych mężczyzn w koszulkach z hasłem this is how feminist looks like.

Wtedy narodzily się pytania: czy kolorowe magazyny o modzie, promujące wyidealizowane wzorce piękna (i które artykułami o cudownych środkach umożliwiają dostosowanie kobiecych ciał do tych wzorców, spełniając wymogi reklamodawców) mogą przekształcić ruch, u którego podstaw tkwią między innymi założenia o obalaniu obowiązującej definicji piękna? Czy zmiana feminizmu faktycznie jest potrzebna? Skąd takie zamieszanie wokół niego?

Polskie media tej samej kategorii podchuyciły temat na przełomie lutego i marca 2015 roku, wynosząc na piedestał pop-feminizm i traktując go jako rozwiązanie niechęci kobiet do feminizmu, określanego głównie jako nastawiony na rozgłos i agresyuny latte-feminizm pań z Kongresu Kobiet. Polskie feministki przez przyjęcie podobnej retoryki, jak ich ideologiczne koleżanki zza oceanu, zostały oskarżone o zagarnięcie

1 Z. Melosik, Tożsamość, ciało i władza: teksty kulturowe jako (kon)teksty pedagogiczne, Wydawnictuo Edytor, Poznań-Toruń 1996, s. 263. 
całej idei na potrzeby konkretnej, wąskiej klasy społecznej - wykształconej i posiadającej pieniądze. Lekarstuem na tę niechęć miało być stworzenie nowych, przystępniejszych dla nowoczesnych kobiet form. Rezultatem stała się postępująca trywializacja pojęcia feminizmu.

\section{Czy gender to feminizm - problemy definicyjne}

Feminizm w najprostszym wymiarze jest ruchem kobiecym, działającym na rzecz praw kobiet od ponad 200 lat. Siłą rzeczy, działając nieprzerwanie od ponad dwóch wieków, wykształcił wiele odłamów i łączy w sobie wiele wręcz sprzecznych myśli. Można go traktować bardzo szeroko i ogólnie jako przeciwwagę dla dyskryminacji kobiet wyrażoną $\mathrm{w}$ formie ruchu o charakterze między innymi politycznym, społecznym, kulturowym i intelektualnym, mającym różne orientacje, szkoły, teorie i badania. Można patrzeć na niego także węziej i praktycznie, jako na ideologię wcielaną u życie lub podstawę (składnik) dyscypliny naukowej, jaką są gender studies, przez co najprawdopodobniej w odbiorze społecznym jedno jest utożsamiane z drugim, tj. gender z feminizmem i na odwrót. Można także przyjąć za nowocześniejszymi teoriami, że feminizm walczy o wyzwolenie kobiet i mężczyzn spod krzywdzącej władzy patriarchatu i seksizmu.

Jednakże z punktu widzenia autorki tej publikacji najbardziej interesujące jest połączenie definicji Agnieszki Graff i bell hooks². Pierusza, pokazująca starania feminizmu o poważne traktowanie kobiet, o pozbawiane nieustannie towarzyszącego im „pobłażliwego uśmieszku” wyraźnie pokazuje, że feminizm uspółcześnie pokazywany $\mathrm{w}$ mediach, feminizm w wersjach latte, pop i girl power bardzo odbiega od standardów wyznaczonych przez jego teoretyków i teoretyczki, a także realnych działań ruchu kobiecego. Druga, mówiąc, że feminizm, który ma coś zmienić, musi być uważany za siłę polityczną, nie może przeobrazić się w jedną z możliwych wersji stylu życia czy tożsamości do wyboru. Takie przekształcenie następuje dzisiaj w mediach, szczególnie w analizowanej kategorii magazynów segmentu luksusowego dla kobiet.

\section{Trzy fale - krótka historia feminizmu}

Pisząc o ruchu społecznym, którego samo zdefiniowanie nastręcza wiele trudności, a także biorąc pod uwagę mnogość prądów i podejść, nie jest możliwym przyjęcie konkretnej daty, dotyczącej jakieś szczególnego wydarzenia, przełomu czy innego uyraźnie określonego momentu poustania. Ruchy feministyczne i sam feminizm kształtował się stopniowo w różnych krajach i pod wpływem różnych zdarzeń, głównie o charakterze emancypacyjnym.

2 bell hooks, ułaściwie Gloria Jean Watkins - amerykańska pisarka, poetka, feministka „trzeciej fali”, jedna z czołouych przedstawicielek czarnego feminizmu. 
W etap masowego ruchu feminizm wkracza w wieku XIX i to tę, dziewiętnastowieczną, historię włącza się do zuyczajowego podziału na trzy fale. Fale różnią się programem i sposobem definiouania róuności kobiet, stąd móui się róunież o typach feminizmu z nimi związanych - pierwszo-, drugo- i trzeciofalowym. O falach mówi się od czasu, gdy drugofalowe feministki, w tym Marsha (Martha) Weinman Lear, w artykule The Second Feminism Wave z 10 marca 1968 roku $^{3}$ nazwały swoją aktyuność feminizmem „drugiej fali” (second wave feminism), odżegnując się od działań poprzedniczek i nazywając je „pieruszą” (first) lub też „starą” falą (old-wave). Mimo że pouszechnie we współczesnych społeczeństwach zachodnich myśli się o feminizmie w kategoriach nowofeministycznego ruchu drugofalowego zapoczątkowanego książką Betty Friedan Mistyka kobiecości $i^{4}$, na początku lat 90. XX wieku, tym razem w czasopiśmie Ms. Rebecca Walker opublikowała artykuł zatytułowany Becoming Third Wave, nazywając swoje działania trzecią falą ${ }^{5}$ Trzecia fala to odpowiedź na porażkę strategii drugiej fali oraz następstuo rosnącej świadomości znaczenia innych czynników opresji społecznej, jak rasa, seksualność, teoria queer czy nieróuny podział ekonomiczny dla równouprawnienia kobiet itp. Trzecia fala jest etapem, o którego istnienie i zasadność dziejowego wyodrębniania w dalszym ciągu toczą się spory. Część badaczy uznaje tylko dwie pierwsze fale, część umieszcza swoje prace w trzeciofalowym nurcie, kolejni zaś mówią o poustawaniu czwartej fali.

\section{Polska specyfika (lub „Feminizm nigdy nie wydarzył się w Polsce")}

Polski feminizm na tle, wydawałoby się skomplikowanego układu dzieł, postaci i wydarzeń, jaki charakteryzuje jego amerykańską i zachodnioeuropejską wersję, jest jeszcze bardziej poszatkowany i zagmatwany. Z jednej strony w debacie publicznej pojawiają się głosy, że feminizm tak naprawdę nigdy nie wydarzył się w Polsce, szczególnie przed rokiem 1989, z drugiej zaś możemy odnaleźć źródła, które móuią aż o siedmiu falach (z dokładnym wyznaczeniem otwierających i zamykających dat od $1800 \mathrm{r}$. do dziś).

Jednakże na potrzeby prowadzonych analiz przyjęto zaadaptowanie trzech „zachodnich fal" jako podziału bardziej uniwersalnego i chętniej używanego przez same feministki u Polsce. Podział ten stanie się podstawą opisu „oswajania” feministycznych idei, które - także na wzór zachodni - zmieniły się w postfeministyczną dewaluację pojęcia. Szczególnie warta podkreślenia jest zaproponowana przez Samuela

3 M.W. Lear, The Second Feminist Wave, http://womenshistory.about.com/od/feminism-second-wave/a/Martha-Weinman-Lear-Second-Feminist-Wave.htm [dostęp: 1.11.2016].

4 K. Ślęczka, Rola kobiet we wspótczesnych transformacjach społecznych $-w$ zwierciadle feminizmu [w:] Kobiety wobec przemian okresu transformacji, red. K. Faliszek, E. McLean Petras, K. Wódz, Wydawnictuo Śląsk, Katowice 1997, s. 129-141.

5 A. Graff, Trzecia fala feminizmu, http://www.wysokieobcasy.pl/uysokie-obcasy/1,96856, 2715339.html [dostęp: 17.06.2015]. 
Nowaka (a inspirowana pracami Angeli McRobbie ${ }^{6}$ ), koncepcja potrójnego nałożenia. Opisuje on sytuację,

w której dane społeczeństwo nie przyswoiło sobie jeszcze zdobyczy drugiej fali feminizmu [one pojawiają się powoli na poziomie instytucjonalnym i prawnym] $]^{7}$, chociaż funkcjonują u nim już idee typowe dla postfeminizmu, zarówno na poziomie teorii akademickiej [czerpanie wzorców akademickich z zachodu], jak i codziennych praktyk społecznych [przejęcie stylów życia i konsumpcji] oraz [co dla niniejszej pracy najważniejsze] tekstów kultury (książek, seriali, filmów, itd.) [prasa także należy do tego zestauu] ${ }^{8}$.

W skrócie badacz nazywa tę sytuację konserwatywną modernizacją i w takim znaczeniu pojęcie to będzie używane $\mathrm{w}$ tym artykule.

Dzięki globalizacji, za którą idzie coraz sprawniejsza wymiana idei i poglądów na całym świecie, także $w$ Polsce feminizm został odpolityczniony i przemieniony w mediach na pewien rodzaj tożsamości, z którego nowoczesna kobieta może skorzystać, jako jednej z dostępnych opcji i uizerunków. Dzięki kobiecym mediom głóunego nurtu (w tym prasie luksusowej) ta tożsamość (post?)feministyczna jest ukazywana jako jeden z możliwych stylów życia do wyboru, gdzie najpopularniejsze z nich to opisywane w dalszej części pracy - latte-feminizm, pop-feminizm i girl power. Wykorzystanie pojęcia konserwatywnej modernizacji jest tym istotniejsze, że pomogło podkreślić niebezpieczeństwa kryjące się za tworzeniem finezyjnych wersji antyfeminizmu u społeczeństuie, które tak naprawdę posiada niewielką wiedzę na temat myśli i historii ruchu, a także przenoszeniem ich pod płaszczykiem nowych feminizmów. Feminizmów pretendujących do bycia czwartą falą.

\section{Czwarta fala? Trywializacja i upadek politycznego feminizmu}

Odczarowanie feminizmu wydaje się słowem-kluczem dla postfeministycznego dyskursu. Postfeminizmem, za Deborah Rosenfelt i Judith Stacey ${ }^{9}$, nazwano odpolitycznienie postulatów feminizmów kolejnych fal, które było skutkiem wchłonięcia ich przez kulturę popularną i media głównego nurtu. Nowa fala to czas odpolitycznionego paradygmatu Nowej Kobiety i mody na feminizm. Nie jest to jednak feminizm, który znamy z historii ruchu feministycznego i rozwoju idei, opisanych wcześniej. Nie jest to również stereotypouy, agresyuny feminizm, o którego genezie także uspomniano. To pseudofeminizm, który wyrósł z ogromnej krytyki feminizmu, a także zmian na tle społeczno-kulturouym.

${ }^{6}$ A. McRobbie, Postfeminizm i co dalej?, https://mocak.pl/angela-mcrobbie-postfeminizm-i-co-dalej [dostęp: 20.06.2015].

${ }^{7}$ Komentarze w nawiasach kwadratowych pochodzą od autorki tekstu.

${ }^{8}$ S. Nowak, Postfeminizm, kultura popularna $i$ konserwatywna modernizacja [w:] Kobiety w spoleczeństwie polskim, red. H. Szczodry, A. Pałęcka, M. Warat, Wydaunictwo Uniwersytetu Jagiellońskiego, Kraków 2011, s. 215.

9 Ibidem, s. 5. 
Nowa Kobieta to twór, który pociąga za sobą przejście od politycznych haseł i walk o prawa kobiet do feminizmu towarowego zredukowanego do konsumpcji znaczeń. Ponowoczesne kobiety są wykształcone, pracujące zawodowo, bezproblemowo łączące życie zawodowe i rodzinne (albo mające czas na rodzinę i dzieci), niedające się zamknąć w świecie pieluch, garnków i złotej klatki przedmieść. To kobiety, które uważają, że emancypacja została już osiągnięta, nie odczuwają potrzeby dalszej walki o prawa. Czują się równe mężczyznom, nie boją się ich, a wręcz wierzą, że mogą nimi manipulować. Peune siebie i przebojowe, nie chcą etykietki ofiary, ponieważ swoim życiem udowadniają, że świetnie sobie radzą. W bycie panią domu bawią się od święta, u zależności od tego, jak bardzo jest to modne u danej chwili. Są same, egocentryczne, ale nie samotne - otoczone mnóstwem koleżanek i mężczyzn.

Teoretyczki ruchu częściowo obarczają się winą za wykrzywiony obraz feminizmu, który spowodował odpowiedź w postaci powstania postfeministycznych wariantów. Jedną z nich jest Carol Ehrlich, dostrzegająca w powodach wykształcenia się feminizmu mieszczańskiego brak postulatów, które kobiety mogłyby odnieść do realnego życia ${ }^{10}$. Susan Faludi uważa ukształtowanie się feminizmu konsumenckiego za wynik oddzielenia feministycznej walki z nierównością ekonomiczną od walki o równouprawnienie kobiet. $\mathrm{W}$ takim feminizmie

chodzi jedynie o tak zwane uyrażanie siebie przez to, co nosisz, jaką miałaś operację plastyczną, ile wart jest twój dom i tym podobne oznaki statusu [...] Pop-feminizm «jesteś tego warta» mówi kobietom, że emancypacyjne zdobycze były ważne, ale nie warto nimi zaprzątać głowy, bo one już są elementem kobiecej rzeczywistości. Teraz kobiety mogą skupić się na egzekwowaniu tej wolności na polu konsumpcji i wyborach odpowiadającego im stylu życia. Ponadto uspółcześnie, jak podnosi francuska feministka Antoinette Fouque, feminizm stał się mieszczańską awangardą, która podtrzymuje - u oduróconej formie dominujące wartości [...] Mieszczański porządek, kapitalizm i fallogocentryzm chętnie ułączają w swoje struktury tyle feministek, ile potrzebują ${ }^{11}$.

Podobnie Zbyszko Melosik między innymi w rozdziale Postfeminizm i „nowa kobieta ${ }^{\prime 2}$ uspomina o istocie działania systemów inkorporacji, mających bronić współczesnych form dominacji, które polegają na prowokowaniu i zapraszaniu podporządkowanych do uzupełniania niedokończonych znaczeń zawartych w przesyłanych im tekstach kulturowych. Dzięki temu zachowują wrażenie współudziału w sprawowaniu władzy.

Feminizm w tym ujęciu dobrze się sprzedaje w mediach i społecznościach, odesłany do lamusa w poprzednich falach, wraca $\mathrm{w}$ formie walki o wolność do konsumowania - przeżyć, wrażeń czy nowych stylów życia (pop-feminizm), wolność

10 B. Hooks, Teoria feministyczna. Od marginesu do centrum, tłum. E. Majeuska, Wydawnictwo Krytyki Politycznej, Warszawa 2013, s. 38.

11 Ibidem, s. 37.

12 Z. Melosik, Tożsamość, ciało i władza w kulturze instant, Oficyna Wydaunicza Impuls, Kraków 2010, s. 122. 
i poparcie w przebijaniu szklanego sufitu i walce o „suwak” w polityce (latte-feminizm) czy wreszcie wolność seksualną i wykorzystywanie krzywdzących stereotypów na swoją korzyść, do manipulowania mężczyznami (girl power). Młode kobiety zainteresowane są ruchem jakby „przyciętym” do ich potrzeb i zainteresowań. O zmniejszonej radykalności, a opowiadającym się za indywidualizmem, wyzwoleniem seksualnym, zainteresowaniem kulturą popularną i konsumpcjonizmem (tak demonizowanym i odrzucanym wcześniej). W konsekwencji ,zakwestionowany zostaje jego potencjał polityczny, a wraz z tym możliwość inicjowania zmian społecznych"13. A jeśli zakwestionuje się polityczną wartość jakiegokolwiek ruchu społecznego, zostaje aspekt ideologiczny, który kultura masowa łatwo przemienia w styl życia.

Te feminizmy-style życia uspółcześnie najczęściej występują pod postaciami: latte-feminizmu, pop-feminizmu i feminizmu w stylu girl power. Piętnaście lat temu popfeministki zostały zaliczone do kategorii „kobiet, które - choć niejednokrotnie realizują ideały feminizmu - sprzeciwiają się jakiejkolwiek identyfikacji z tym ruchem" ${ }^{\prime 4}$. Dziś nie można się z tym tuierdzeniem zgodzić. Obecnie media, odsyłając u przeszłość poprzednie, polityczne fale, uważają postfeminizmy za jedyne, właściwe drogi rozwoju.

Krytycy tego zjawiska twierdzą, że uzyskanie poczucia autonomii, korzystając z jednego z postfeminizmów (a dokładniej z postfeministycznego stylu życia), jest karykaturą rzeczywistej emancypacji, która przecież nie powinna polegać na tworzeniu enklaw znaczeń, ale na zmianie rzeczywistości społecznej, w której ludzie żyją. Sukces w mediach głównego nurtu wiąże się zatem z końcem autentyczności i odmienności.

\section{Latte, pop czy girl power?}

Badanie trywializacji feminizmu w mediach pod trzema postfeministycznymi postaciami nie mogło się obyć bez ich zdefiniowania. Latte-feminizm nazywany bywa feminizmem korporacyjnym lub akademickim, co dobrze oddaje charakter tej „wersji”. Stereotypowo latte-feministki zajmują się obrazem kobiety w (pop)kulturze, seksualnością kobiet i zjawiskami dyskryminacji w miejscu pracy. Drugi typ, pop-feminizm, to uspółcześnie najmocniej popularyzowana tożsamość feministyczna w pismach kobiecych. Pop-feministki, wzorując się na gwiazdach popkultury czy celebrytach (ta wersja jest określana także jako feminizm popkulturowy czy gwiazdorski), uważają się za kobiety wyzwolone, twierdzące, że postulaty emancypacyjne zostały już osiągnięte, że „ich feminizm” wykracza znacznie poza wyzwolenie kobiet. Trzecią i ostatnią omawianą formą trywializowania będzie tożsamość girl power, czyli pseudoemancypacyjny dyskurs dziewczyny-kobiety skupiony na seksualności i ciele.

13 P. Gąsiorek, Postfeminizm, popfeminizm, anty-antyfeminizm... czyli o dalszym (p)oszukiwaniu kobiety [w:] Edukacja. Społeczne konstruowanie idei i rzeczywistości, red. M. Cylkouska-Nowak, Poznań 2000, s. 414.

14 Ibidem, s. 419. 
Z braku naukowych definicji i opracowań w dziedzinie, które można uznać za wyczerpujące, zdecydowano się sięgnąć do artykułów prasowych, w których pojawiały się operacjonalizowane pojęcia. Po zapoznaniu się z autorskimi opisami tych feminizmów i kontekstem, w jakim uystępowały, stuorzono osobne definicje przez połączenie najczęściej powtarzających się w tekstach cech, z wyjątkouymi dla każdego autora określeniami.

Uniwersalizując własne doświadczenie, latte-feministki zajmują się wyłącznie sprawami, z którymi bezpośrednio się spotykają, nazywanymi pogardliwie ich feministyczną fantazją. Akcentują wagę i prostotę łączenia życia zawodowego z domowym (przecież istnieją pomoce domowe). Oderwanymi od życia przeciętnej kobiety i krążącymi wokół ich środowiska, a więc poniżającym obrazem kobiety w (pop)kulturze, ograniczaną instytucjonalnie wolnością wyborów związanych ze sferą seksualności kobiet, agitacją wartości sukcesu ekonomicznego i bycia superwoman na rynku pracy. Wierzą bowiem we własne siły i siły kobiet. Feminizm traktują jako źródło inspiracji twórczych lub jako siłę polityczną, która ma im pomóc w odniesieniu sukcesu politycznego ${ }^{15}$. Ten nurt uznano za najmniej strywializowany rodzaj postfeminizmu.

Do tej kategorii zaliczono artykuły, które pozytyunie wartościują walkę o prawa reprodukcyjne kobiet (m.in. prawo do aborcji, refundację antykoncepcji i zabiegów in vitro), ustanawianie parytetów uyborczych (w tym suwaka, czyli naprzemienności wchodzenia na listy kobiet i mężczyzn, bez specjalnych procentouych wartości regulujących odpowiedni stosunek kobiet do mężczyzn) i walkę ze zjawiskami dyskryminacji w miejscu pracy. Popierają także kobiecą zaradność ekonomiczną i indywidualizm, a jednocześnie zachęcają do uspółtworzenia Kongresu Kobiet, jako miejsca wymiany indywidualnych doświadczeń i opinii. Natomiast negatywnie wartościują istnienie instytucji szklanego sufitu, dyskryminację w miejscu pracy, brak wystarczającego udziału kobiet u tzw. wielkim biznesie i polityce, a także seksizm, jaki panuje w tych dziedzinach.

„Feminizm jeszcze nigdy nie był tak bardzo glamour. Duża w tym zasługa guiazd, które chcą się z nim identyfikować" - tymi słowami zaczyna się artykuł Słowo na f, zamieszczony w marcowym wydaniu polskiej edycji „Elle” ${ }^{\text {. }}$. Pop-feminizm zawiera w sobie zarówno elementy zdroworozsądkowej emancypacji (ale w zdecydowanie mniejszym stopniu), jak i tzw. pozy na feminizm, wzorowanej na gwiazdach i osiąganej przez odpowiednie decyzje zakupowe i walkę o wolność do tych decyzji. Feministki w stylu pop uważają się za kobiety wyzwolone, twierdzące, że postulaty emancypacyjne zostały już osiągnięte, że „ich feminizm” wykracza znacznie poza wyzwolenie kobiet. Zbyszko Melosik uważa, że pop-feminizmowi najbliżej do feminizmu towarowego, czyli mieszanki wybranych (nie za bardzo skomplikowanych) idei ruchu kobie-

15 Ibidem, s. 421.

16 M. Stukonis, Od Redaktora, http://wuw.elle.pl/magazyn/2015-elle-3 [dostęp: 1.11.2016]. 
cego, społecznie uznanego i podziwianego ideału kobiecości i całej ideologii konsumpcji ${ }^{17}$. Pop-feminizm mówi: stwórz (kup) własną wersję tożsamości feministycznej.

Do tej kategorii zaliczono teksty powiązane z gwiazdorskim życiorysem, a także te, które pozytyunie wartościują: walkę z "terrorem piękna”, wzmacniają akceptację własnego ciała, przekonują kobiety o wolności do konsumpcji przez podejście ,jesteś tego warta". Opisują one także: partnerstwo w związku, pełne korzystanie z życia - we wszystkich sferach i na uszystkie sposoby, łączenie kobiecego uyglądu i emancypacji, przeciustawianie się stereotypom podrzędności kobiet względem mężczyzn i innym, na przykład „baby za kierownicą”, a także mają za cel obalanie seksualnego i erotycznego tabu.

Ponadto uznano zasadność wyodrębnienia z pop-feminizmu trzeciego typu postfeministycznego dyskursu, mimo że Zbyszko Melosik (i inni badacze, powołując się na niego, na przykład Przemysław Gąsiorek ${ }^{18}$ czy Samuel Nowak ${ }^{19}$ ) podchodzi do niej bardziej jako do cechy opisywanego wcześniej pop-feminizmu niż do odrębnego zjawiska ${ }^{20}$. Pop-feminizm jest skupiony na wolności konsumpcji, gwiazdach popkultury i walce ze stereotypami, natomiast feminizm girl power koncentruje się na wykorzystywaniu stereotypu na swoją korzyść, na wizerunku silnej kobiety-wojouniczki i wreszcie na seksualności, młodości (stąd girl, nie zaś woman power) i ciele.

Girl power to dziewczęcość agresywna i świadome uykorzystywanie jej do panowania nad mężczyznami i manipulacji do osiągnięcia własnych celów, czyli w tym wypadku uwodzenia. Jest to najbardziej strywializowana postać tożsamości postfeministycznej, gdyż wykorzystuje pierwotny sprzeciw wobec seksizmu i epatowania roznegliżowanym ciałem jako czynnikom upodlającym kobiety i umieszcza je w kategoriach feministycznych. Feministkom girl power zupełnie nie przeszkadza bycie obiektem męskiego spojrzenia i pożądania, są wręcz szczęśliwe, jeśli osiągają dzięki temu sukces, z drugiej strony następuje tu także rekonstrukcja podmiotowości kobiety - emancypują się za pomocą kreowania eksponującego kształty wizerunku, manipulowania męskim pożądaniem, dowolnego uyboru partnerów seksualnych i ich częstej zmiany.

Uznano, że mamy do czynienia z girl power, gdy w analizowanych tekstach będzie pozytyunie uwypuklone podkreślanie kobiecej (dziewczęcej) siły, opisywanie sposobów na uwodzenie mężczyzn przez podkreślanie lub maskowanie makijażem i ubiorem (a nawet operacjami plastycznymi) swojego ciała i urody czy nauka nowych seksualnych technik. W artykułach pozytywnie wartościowana będzie młodość, dziewczęcość, otwartość seksualna, spędzanie czasu wolnego na zakupach i innych aktywnościach przypisanych jednoznacznie do płci, natomiast negatywnie wartościowane będą: feminizm poprzednich fal, niedbały, stereotypowo feministyczny uygląd,

\footnotetext{
17 Z. Melosik, Tożsamość, ciało i władza w kulturze instant, op. cit., s. 122.

18 P. Gąsiorek, op. cit., s. 419.

19 S. Nowak, Postfeminizm, kultura popularna..., op. cit.

20 Z. Melosik, op.cit., s. 123.
} 
podnoszenie idei równości płci, walka z seksizmem, nienawiść feministek do mężczyzn.

Te tożsamości nie posiadają manifestów, ideologicznych założeń teoretycznych, pism, liderek czy prekursorek uznanych przez większość. Życie ponowoczesnej kobiety, podobnie jak mężczyzny, polega na ciągłym przedefiniowywaniu siebie i swojej tożsamości, korzystając z całego wachlarza możliwości, których dostarcza im postmodernistyczna rzeczywistość. Idee, prądy myślowe, ruchy społeczne i subkultury stają się uspółcześnie niczym więcej niż wchłoniętymi i strywializowanymi przez główny nurt kultury opcjami, które można wybrać i skonsumować na własne potrzeby, dowolnie je ze sobą łącząc. Ta kultura wchłania je tym chętniej, im bardziej pierwotnie były krytyczne, czy wobec niej wywrotowe, gdyż dając im rozgłos równocześnie je odpolitycznia i obezwładnia. „Poważna” związana z klasą średnią i jej problemami kobieta będzie zainteresowana feminizmem bliskim tradycji liberalnej, czyli wersją latte. Młoda, wyemancypowana mieszczanka, wierząca w wyczerpanie idei feminizmu przez ich dokonanie u społeczeństwie i obecność w codziennym życiu, dla której ważna jest kultura pop, sięgnie po postulaty dotyczące prawa do konstruowania ułasnej tożsamości i wolności u sferze konsumpcji, czyli pop-feministyczne. Trzecią najpopularniejszą i, jak się wydaje, najmłodszą z wymienionych tu grupą są kobiety, które świadome swojej wartości chętnie czytają teksty, które uczą podkreślania siły kobiet/dziewcząt leżącej u podstaw uwodzenia i manipulowania męskim pożądaniem. Dla nich podkreślanie seksistouskiej opresji mężczyzn nad kobietami ma charakter zniechęcający je do tradycyjnie pojmowanego ruchu feministycznego (który przy okazji traktują jako niewarty zaangażowania relikt przeszłości) i nie chcą tym odstraszać mężczyzn, których zainteresowanie jest dla nich ważne, sięgną więc po feminizm girl power.

\section{Czy feminizm jest trywializowany?}

Te trzy wersje tożsamości czy typów ponowoczesnego pseudofeminizmu są uyraźnymi przejawami trywializacji pierwotnego pojęcia, związanych z nim idei i powagi im należnej. W tej analizie prasa ilustrowana segmentu luksusowego została ujęta jako inspirator zmian w odbiorze feminizmu. Pracę oparto na zbadaniu wyróżnionych form trywializacji w wydaniach „Twojego Stylu”, „Wysokich Obcasów”, „Wysokich Obcasów Extra” i „Cosmopolitan” z sześciu pierwszych miesięcy 2015 roku. Wybór oparto na własnej wiedzy i doświadczeniu związanym z rynkiem prasy tego segmentu w Polsce. Wybrane do analizy tytuły najlepiej odpowiadają zarówno tematowi pracy, jak i przeprowadzonym badaniom. Przyjrzano się bowiem uspomnianym tytułom i przypisano je do odpowiadających im „feminizmów”, czyli kolejno - latte-feminizm przypadk „Twojemu Stylowi”, pop-feminizm - „Wysokim Obcasom” i „Wysokim Obcasom Extra”, girl power zaś czasopismu "Cosmopolitan”. Rozważono także dopasowanie wersji postfeminizmu do kapitału kulturowego/statusu społecznego odbiorców tych 
tytułów przez stworzenie profili kobiet potencjalnie zainteresowanych danym dyskursem. Analiza tych materiałów dała podstawę do wnioskowania na temat samej trywializacji oraz podjęcia próby odpowiedzi na pytania: komu ona służy? Jak się przejawia u dyskursie publicznym?

Uznając zdanie jednej z czołowych polskich feministek Kingi Dunin, że „liberalny feminizm [...] przypisując nadmierną rolę warunkom kulturowym, często jest zbyt wygodnym partnerem dla neoliberalnych praktyk. I zbyt łatwo zmienia się w pop-feminizm kolorowych pisemek kobiecych" ${ }^{21}$, sprawdzono, które postulaty tradycyjnie pojmowanego feminizmu zostały przejęte przez kolorowy i luksusowy prasouy dyskurs na potrzeby „nowych feminizmów” i na ile odzwierciedlają one prawdziwe projekty ruchu kobiecego. Miało to na celu sprawdzenie roli, czy też znaczenia prasy luksusowej w trywializacji pojęcia, a także wartościowania samego procesu. Być może trywializacja nie jest złą rzeczą, tylko „skrojoną na miarę” odpowiedzią na żądania społeczne? Podsumourując, niniejsza analiza jest próbą odpowiedzi na pytania: dlaczego trywializacja zachodzi i komu służy. Jaką tematykę poruszają artykuły określane przez redakcje lub odbierane przez czytelniczki jako feministyczne? Czy wreszcie „nowe feminizmy” są uspółczesną mistyką kobiecości, tylko inaczej nazwaną? I czy można ją, tę mistykę, nazwać początkiem czwartej fali w dziejach feminizmu? W odpowiedzi na te pytania pomogły pytania dodatkowe między innymi o niebezpieczeństwa, jakie kryją się za popularyzacją treści niefeministycznych, a związanych z ruchem kobiecym przez nazewnictwo.

W badaniach empirycznych oparto się na technice krótkiej analizy zawartości, łącząc ją z metodą krytycznej analizy dyskursu. Wykorzystanie analizy zawartości pomogło scharakteryzować tytuł i wskazać najważniejsze tendencje, jakie wiążą go $\mathrm{z}$ trywializowaniem dyskursu feministycznego. Tendencje posłużyły do wyboru reprezentacyjnej próby, niezbędnej w przeprowadzeniu kolejnego etapu, jakim była krytyczna analiza dyskursu. Wybór tych metod i technik badawczych nie był przypadkowy. Krytyczna analiza dyskursu „dąży do systematycznego badania ukrytych relacji przyczynowości i determinowania zachodzących pomiędzy tekstami, zdarzeniami i praktykami dyskursywnymi oraz szerszymi strukturami, relacjami i procesami społecznymi i kulturowymi”22. Zatem było to doskonałe narzędzie do odpowiedzi na postawione pytania badawcze i, przede wszystkim, do weryfikacji hipotez.

Po przeanalizowaniu wyników przeprowadzonych badań zauważono następujące trendy w badanej populacji/korpusie. Feminizm jest dziś bezsprzecznie trywializowany u kobiecej prasie segmentu luksusowego. Szczególnie popularnym przejawem tej trywializacji jest feminizm typu girl power. W badanych magazynach chętnie występuje razem z przejawem w wersji pop, czyli pop-feminizmem. Zjawisko to potwierdzają także uskazania, że w prawie połowie tekstów feminizm już się dokonał i pozostaje

21 N. Fraser, Drogi feminizmu. Od kapitalizmu państwowego do neoliberalnego kryzysu, tłum. A. Weseli, Wydawnictwo Krytyki Politycznej, Warszawa 2014, s. 7.

${ }_{22}$ M. Lisouska-Magdziarz, Analiza tekstu w dyskursie medialnym, Wydawnictwo Uniwersytetu Jagiellońskiego, Kraków 2006, s. 22. 
korzystać z tego zuycięstwa. Odnalezienie tendencji głównych, jak i przynależnych konkretnym tytułom w badanej populacji, było koniecznym krokiem do kolejnej części badań empirycznych - krytycznej analizy dyskursu.

Badanie miało charakter opisouy i odnosiło się do najważniejszych tendencji trywializacyjnych w wymienionych tytułach. Artykuły poddane analizie wyodrębniono na podstawie przeprowadzonej analizy zawartości. Tendencje te są następujące:

1. Różoua siła. Najuażniejszym przejawem trywializacji feminizmu w mediach jest obecność dyskursu girl power. Elementy z nim zuiązane zauważono prawie w połowie badanych tekstów we wszystkich tytułach. Pomniejszym trendem jest popularność łączenia idei silnej dziewczyny z pop-feminizmem (12\%). Nazwano to pogłębionym stopniem trywializacji dyskursu, gdyż obydwie formy cechuje największe odpolitycznienie i odłączenie powagi w działaniach i postulatach. Interesujący jest fakt, że nawet w pismach o mocnym latte-feministycznym charakterze występowały śladowe ilości tego dyskursu. Może to świadczyć o świadomym włączaniu się w trend w celu pozyskania większej liczby czytelniczek lub, patrząc z drugiej strony, istotności podkreślających dzieuczęcą/kobiecą siłę i wyzwoloną seksualność haseł dla uspółczesnych kobiet i/lub społeczeństua konsumpcji.

2. Kobieta jako projekt. Feministyczny dyskurs w badanym segmencie mediów opiera się na wizerunku i tematyce z nim związanej. Blisko jedna czwarta artykułów zawierała troskę o wizerunek kobiety, w formie między innymi nawoływań do akceptacji swojego ciała, walki z terrorem piękna czy zmagań ze stereotypouym przestawieniem kobiety. Podkreślona w nich jest także odwaga bycia sobą i znaczenie samorealizacji w życiu współczesnej kobiety. Emancypacja w nich przedstawiona opiera się na konsumpcji i tworzeniu siebie „na nowo” w ramach wybranego stylu życia „możesz uszystko”. Jest również odczarowaniem obrazu agresywnej, brzydkiej feministki - możesz być już kobieca, osiągnęłaś swój cel.

3. Jesteśmy takie jak Ty. Rola „zuykłej kobiety” jest najczęściej przyjmowaną przez analizowane tytuły. Aż w 48\% przypadków to właśnie o niej lub dla niej były pisane teksty. Uznano to za istotne w kontekście odpowiedzi na zarzuty o odrealnienie tradycyjnego feministycznego dyskursu i jego ekskluzywność klasową. Jest odczarowaniem także roli agresywnej, brzydkiej feministki.

4. Emancypacja dokonana. Prawie połowa badanych tekstów przedstawiała kobietę, która już nie potrzebuje walczyć o feministyczne ideały, bowiem ich realizacja została prawnie zagwarantowana, pozostała jej walka o sukces w ramach własnej biografii. Indywidualne szczęście. Zmagania są inspirowane przedstawieniami syluetek kobiet sukcesu i gwiazd na łamach pism luksusowych. Nowoczesne kobiety uczone są wielozadaniowości i zaradności życiowej od dziecka, nie podoba im się uczucie bezradności, które wywołuje w nich zaangażowanie w ruch. Postfeminizmy są lekiem na tę bezradność.

5. Brak. Badaczka wychodzi z założenia, że nieobecność pewnych tematów, ról społecznych i innych uskaźników, podobnie jak ich wysoka popularność w badanym 
dyskursie, jest wartym odnotowania zjawiskiem. Postfeministyczne dyskursy mówią bardzo mało, albo nic, na tematy z kategorii „poważnych”. Edukacja i prawo były zupełnie pomijanymi zbiorczymi kategoriami tematów, a kategoria rynek/ekonomia/ gospodarka pojawiła się w badaniach w ilości graniczącej z błędem statystycznym. W kategorii typy dyskursu latte-feminizm, jako „najpoważniejszy” strywializowany dyskurs, cieszył się najmniejszą popularnością. Prowadzi to do ustaleń podobnych do punktów 1. i 4., czyli wnioskowania o trendzie na pogłębianie odpolityczniania feminizmu i niechęci kobiet do poczucia bezradności.

Analizę dyskursu przeprowadzono na konkretnej próbie. Rozbiorowi na czynniki pierwsze poddano warstuę językową tekstu, a sam dyskurs potraktowano jako sposób użycia języka do przekazywania idei i osiągania określonych celów. W tym celu skorzystano ze ścieżki kolejnych kroków w analizie języka dyskursu zaproponowanej przez Małgorzatę Lisouskąa-Magdziarz ${ }^{23}$. Na podstawie tej ścieżki analizowano elementy związane przede wszystkim ze słownictwem, stereotypami, do których autorzy odwołują się w tekstach i stosowaniem różnych ram w opisie feminizmu przez te pisma.

Na polu, którym jest dyskurs ilustrowanej prasy kobiecej segmentu luksusowego, współczesny dyskurs feministyczny podlega kilku najczęstszym sposobom ramowania. Ramy konceptualne i towarzyszące im skonwencjonalizowane strategie reprezentacyjne podzielono na dwie części.

Pierusza dotyczy opisywania „starego” bądź „tradycyjnego” feminizmu. W większości przypadków nie łączy się ona z tworzeniem nowych wersji przykrojonych na potrzeby czytelniczek czy samego tytułu. Najczęstsze ramy, jakie występują w tej części, to:

- feminizm jako bank gnieuu (ramowanie hegemoniczne w tej części);

- feminizm jako zbiór sfrustrowanych seksualnie, zaniedbanych kobiet noszących wielkie gacie (feminizm versus praudziwa kobiecość);

- feminizm jako radykalna walka, uydzieranie mężczyznom ich obszarów dominacji;

- feminizm „mamy XXI wiek” - dokonany;

- marginalnie - feminizm jako intelektualna elita skupiona na własnych (klasy średniej) problemach.

W tych ramach opisy feminizmu odwzorowują część stałego repertuaru strategii medialnych w przedstawianiu protestów, który opisał Todd Gitlin, tj. trywializację poprzez umniejszanie, ośmieszanie („zaniedbana”, „wielkie gacie”, „sfrustrowana seksualnie”), polaryzację jakiejś skrajności (retoryka wojny i konfliktu - „bojouniczki o sprawę”, „wojujące feministki”, „zabić każdego faceta”, nacisk na konflikty wewnętrzne („Z opozycji między dwiema najbardziej znanymi feministkami w Polsce rozpętała się [ureszcie] pierwsza dyskusja o tym, nad czym tysiące Polek głowiły się wcześniej całe

${ }^{23}$ Ibidem, s. 53. 
lata w samotności” $)^{24}$. W ten sposób media nie tylko wpisują się w dobrze utrwalone społeczne stereotypy, dotyczące zarówno feminizmu i feministek, jak i kobiecości oraz wizerunku kobiety, ale jak zauważono przy opisie stereotypów, przyczyniają się do utrualenia tych krzywdzących konwencjonalnych wyobrażeń u społeczeństuie.

Druga część ramowania odnosi się do tzu. nowych feminizmów. Jest to odniesienie implicytne - przez słownictuo, a także orzeczenia o rzeczywistości. Ramy te w sposób zdecydowanie bardziej pozytywny odnoszą się do feminizmu, jednakowoż mamy tu do czynienia z jego post- lub pseudowersją:

- feminizm jako nowa, lifestylowa kobiecość, wizerunek (także na wzór gwiazd) (ramowanie hegemoniczne w tej części);

- feminizm jako propagowanie wolności, możliwości wyboru (przede uszystkim u seksualności, dobieraniu partnerów, do operacji plastycznych, np. piersi, ale także w prawach reprodukcyjnych);

- feminizm jako przestrzeń kobiecości peunej siebie - tzw. feminizm „jesteś tego warta";

- feminizm rozbudzonej seksualności, bycia „sexy”;

- feminizm indywidualizmu „każdy sobie narzuca rolę, jaką chce”, „sukces w ramach własnej biografii";

- feminizm kobiety sukcesu, która „niczego już nie musi udowadniać”;

- feminizm kobiecej uspółpracy, uspierania, działania, armii dziewczyn (girl power);

- feminizm dumnego, nowego pokolenia kobiet.

Mimo braku ram stuprocentowo pokrywających się z opisywanymi przejawami trywializacji - latte-feminizmem, pop-feminizmem i girl power, wymienione i opisane ramy stanowią ich elementy składowe. Na latte-feminizm składają się głównie ramy: kobieta sukcesu, kobieca współpraca, działanie i sukces w ramach własnej biografii, ale negatywnie ramowany jako intelektualna elita skupiona na problemach klasy średniej. Pop-feminizm zbiera w sobie ramy dotyczące nowej kobiecości feministycznej, dumnego, nowego pokolenia kobiet, które już uszystko mogą, ramy kobiecości pewnej siebie - konsumpcjonistyczny feminizm ,jesteś tego warta”, a także ramę negującą poprzednią ideologię ruchu kobiecego - „mamy XXI wiek” - feminizm się dokonał, kobiety powinny więc z tego korzystać. Ostatni przejaw trywializacji - girl power skupia u sobie najpopularniejsze ramy, w tym jedną hegemoniczną, dla drugiej opisywanej przeze mnie części. Ramy wchodzące $w$ dyskurs silnej dziewczyny to: feminizm jako nowa, lifestylowa kobiecość, kreacja wizerunkowa i cielesna (wolność operacji plastycznych), rama rozbudzonej seksualności, bycia „sexy”, kobiecej uspółpracy, uspierania, armii dziewczyn. Sprzeciwia się ramowaniu feministek jako zbioru sfrustrowanych seksualnie, zaniedbanych kobiet noszących wielkie gacie (feminizm versus prawdziwa kobiecość).

${ }^{24}$ A. Graff, Jesteś urocza, kiedy się złościsz. Radykalny feminizm drugiej fali a media głównego nurtu [w:] Kobiety, feminizm i media, red. E. Zierkiewicz, I. Kowalczyk, Stowarzyszenie Kobiet KONSOLA, Poznań-Wrocław 2005, s. 49. 
Wyniki krytycznej analizy dyskursu, podobnie do wyników analizy zawartości, pokazały, że wizerunek i posttożsamość feministyczna girl power okazały się najpopularniejsze wśród badanych artykułów. Dodatkowo jednoznacznie uykazana została trywializacja feminizmu. Problematyka feministyczna przedstawiana na łamach magazynów kobiecych segmentu luksusowego powinna działać zarówno na korzyść kobiet, jak i samego ruchu z nimi związanego. Powinna przez swoją rozrywkową formułę w lekki i przyjemny sposób podnosić kwestie związane z równouprawnieniem kobiet i mężczyzn, korzystając przy okazji z zaufania, jakim segment tych pism darzą ich czytelniczki. Tymczasem krytyczna analiza dyskursu potwierdziła już dość jednoznaczne wyniki - feminizm, a właściwie moda na pseudofeminizm w tych tytułach działa bardziej anty- niż prokobieco. Utrwala krzyudzące stereotypy i schematy, znacząco odpolitycznia postulaty ruchu, jemu samemu przy okazji odejmując powagi. Czasopisma te są zorientowane na osiąganie własnych, także finansouych celów, powielają zachodnie schematy, wśród których najniebezpieczniejsze są: ramowanie feminizmu jako ruchu/ideologii dokonanej (już nic nie trzeba, uszystko mamy), jak również ramowanie polegające na feminizmie jako wizerunku czy stylu życia. Pierwsza bowiem zakłada brak jakichkoluiek działań, druga - skupienie na konsumpcji, „sprzedaży ideałów” i odwrócenie się od jednego z najbardziej reprezentatywnych postulatów, a mianowicie walki z terrorem piękna proponowanym przez mainstreamoue media. Ponadto przejęcie zachodnich wzorców to stracona szansa na wyrwanie czytelniczek i szerzej, całego społeczeństwa, z rzeczywistości konserwatywnej modernizacji, o której już pisano, przywołując słowa Samuela Nowaka.

\section{Podważenie status quo - niemożliwe?}

Myśl feministyczna była od zausze myślą krytyczną, podważającą status quo, natomiast zmiany, jakie zaszły $w$ interpretowaniu jej na łamach kobiecej prasy ilustrowanej segmentu luksusowego, zostały odebrane przez autorkę tego artykułu jako głęboko negatyune, uderzające $u$ jej centrum. Analizowane tytuły ukazują odpolitycznioną i strywializowaną wersję feminizmu, którą eufemistycznie nazywają „odczarowaniem”, pokazują kwestie podnoszone przez teorię emancypacji jako dostępną dla każdego, pop-teorię „przyciętą" na potrzeby swojej grupy docelowej i przedstawioną w takiej formie, którą masowi odbiorcy mogą zaakceptować. Można uznać, że pisma te są w swojej wymowie antyfeministyczne, co najwyżej emancypacyjno-liberalne, piszące co prawda o sprawach kobiecych, ale na pewno nieposiadające feministycznego charakteru, z którymi są społecznie kojarzone lub przez który same się definiują, jak na przykład „Wysokie Obcasy”.

Wyniki przeprowadzonych badań potwierdziły hipotezy o trywializacji dyskursu feministycznego w kobiecej ilustrowanej prasie segmentu luksusowego. Hipotezy poboczne opierały się na dopasowaniu wersji postfeminizmu do danego tytułu. Tutaj badania przyniosły największe niespodzianki. Zdecydowanie pokryły się prognozy 
o dopasowaniu dyskursu girl power do „Cosmopolitan” i mieszanki latte-pop do „Wysokich Obcasów”. Natomiast badania tytułów „Wysokie Obcasy Extra” i „Twój Styl" przyniosły konieczność zamiany dotyczących ich hipotez pobocznych miejscami - z założenia latte-feministyczny „Twój Styl” okazał się esencją wersji pop, a domniemanie pop-femnistyczne, młodsze i szybciej reagujące na trendy „Wysokie Obcasy Extra" - flagouym przykładem latte-feminizmu. Zaskoczyła także obecność dyskursu silnej dziewczyny w każdym z analizowanych tytułów.

Najważniejszym przejawem trywializacji feminizmu w mediach jest obecność dyskursu girl power. Pomniejszym trendem jest popularność łączenia idei silnej dziewczyny z pop-feminizmem. Uznano to za pogłębienie trywializacji dyskursu, gdyż obydwie formy cechuje największe odpolitycznienie i odłączenie powagi $w$ działaniach i postulatach. Interesujący jest fakt, że nawet w pismach o mocnym latte-feministycznym charakterze występowały śladowe ilości tego dyskursu. Może to świadczyć o świadomym włączaniu się $w$ trend $u$ celu pozyskania większej liczby czytelniczek lub, patrząc z drugiej strony, istotności podkreślających dzieuczęcą/kobiecą siłę i wyzuoloną seksualność haseł dla uspółczesnych kobiet i/lub społeczeństua konsumpcji. Trend ten jest niezależny od kapitału kulturowego grupy docelowej, do której jest kierowany. Nie zauważono tendencji do przedstawiania go na przykład $w$ formie kampu grupie o wyższym kapitale. Feministyczny dyskurs w badanym segmencie mediów bazuje na wizerunku i tematyce z nim związanej. Emancypacja w nim przedstawiona opiera się na konsumpcji i tworzeniu siebie „na nowo” w ramach wybranego stylu życia - „możesz uszystko”. Jest także odczarowaniem obrazu agresyunej, brzydkiej feministki - możesz być już kobieca, osiągnęłaś swój cel. Rola „zuykłej kobiety” jest najczęściej przyjmowaną przez analizowane tytuły rolą. Można uznać, że jest to odpowiedź na zarzuty o odrealnienie tradycyjnego feministycznego dyskursu i jego ekskluzywność klasową. Także swego rodzaju odczarowanie roli agresywnej, brzydkiej feministki. Interesującym dla mnie zjawiskiem był brak tematów „poważnych”. Edukacja i prawo były zupełnie pomijanymi zbiorczymi tematycznymi kategoriami, a kategoria rynek/ekonomia/gospodarka, jak już uspomniano, pojawiła się w badaniach w ilości graniczącej z błędem statystycznym. Wyniki krytycznej analizy dyskursu potwierdziły wyniki z analizy zawartości, dodatkowo uwypuklając różnice pomiędzy trzema strywializowanymi typami dyskursu - latte-feminizmu, który jest skoncentrowany na społeczeństwie, pop-feminizmu, który skupia się na wizerunku i girl power, czyli dyskursu cielesności, seksualności i relacji damsko-męskich.

Procesy, o których była mowa w tym artykule, spłycają obraz i odbiór zarówno feminizmu, jak i jego przedstawicielek. Powodują, że dyskurs publiczny, w tak znaczących dla kobiet mediach, czyli prasie ilustrowanej segmentu luksusowego, zamiast na merytorycznych postulatach i ideach równościouych skupia swoją uwagę na dodatkowym plątaniu już i tak zagmatwanej rzeczywistości konserwatywnej modernizacji przez: uyśmiewanie i deprecjonowanie zaróuno ruchu kobiecego, jak i jego przedstawicielek oraz promowanie pseudofeministycznych wersji jako „nowego, lepszego feminizmu". 
Polskie społeczeństwo, w opinii autorki charakteryzujące się bardzo szczątkową wiedzą na temat ruchu kobiecego i teorii emancypacyjnych, mniej krytycznie odnosi się do tekstów, które je trywializują, gdyż nie ma utrwalonej ramy konceptualnej, punktu wyjścia, dzięki któremu negocjowanie znaczeń może być możliwe. Rezultatem tej chwilowej mody na feminizm i spowodowanych tą modą procesów jest zmiana postaw społecznych i społecznego myślenia o feminizmie oraz osłabienie politycznej siły postulatów, czyli siły realnej zmiany rzeczywistości społecznej. Postfeminizmy mogą przejść do społecznej świadomości jako czwarta fala feminizmu, nowa mistyka kobiecości i tym samym udaremnić zmiany społeczne, do których dąży polityczna i radykalna wersja ruchu emancypacyjnego. Dlatego tak ważne jest analizowanie pozycji feminizmu i ruchu feministycznego w śuiecie mediów i dbanie o to, by głosy, postulaty i opinie feministek w tradycyjnym ujęciu, powróciły na łamy mediów głównego nurtu. Czyż feminizm w mediach naprawdę musi być upraszczany i ograniczany do chuytliuych haseł? Czy takiego feminizmu potrzebują kobiety?

\section{Bibliografia}

Fraser N., Drogi feminizmu. Od kapitalizmu państwowego do neoliberalnego kryzysu, thum. A. Weseli, Wydawnictwo Krytyki Politycznej, Warszawa 2014.

Gąsiorek P., Postfeminizm, pop-feminizm, anty-antyfeminizm... czyli o dalszym (p)oszukiwaniu kobiety [w:] Edukacja. Spoteczne konstruowanie idei i rzeczywistości, red. M. Cylkouska-Nowak, Wydawnictuo Wolumin, Poznań 2000.

Graff A., Feminizm - trzy trudne tematy, http://www.bezuprzedzen.org/doc/polityka_poziom _lokalny.pdf [dostęp: 20.06.2016].

Graff A., Jesteś urocza, kiedy się z tościsz. Radykalny feminizm drugiej fali a media głównego nurtu [w:] Kobiety, feminizm i media, red. E. Zierkiewicz, I. Kowalczyk, Stowarzyszenie Kobiet KONSOLA, Poznań-Wrocław 2005.

Graff A., Trzecia fala feminizmu, http://uww.wysokieobcasy.pl/wysokieobcasy/1,96856, 2715339.html [dostęp: 17.06.2015].

Hooks B., Teoria feministyczna. Od marginesu do centrum, tłum. E. Majewska, Wydawnictwo Krytyki Politycznej, Warszawa 2013.

Lear M.W., The Second Feminist Wave, http://womenshistory.about.com/od/feminism-second-wave/a/Martha-Weinman-Lear-Second-Feminist-Wave.html [dostęp: 1.11.2016].

Lisouska-Magdziarz M., Analiza tekstu $w$ dyskursie medialnym, Wydaunictwo Uniwersytetu Jagiellońskiego, Kraków 2006.

McRobbie A., Postfeminizm i co dalej?, https://mocak.pl/angela-mcrobbie-postfeminizm-i-co-dalej [dostęp: 20.06.2016].

Melosik Z., Tożsamość, ciało i władza: teksty kulturowe jako (kon)teksty pedagogiczne, Wydaunictuo Edytor, Poznań-Toruń 1996.

Melosik Z., Tożsamość, ciało i władza w kulturze instant, Oficyna Wydaunicza Impuls, Kraków 2010.

Nowak S., Postfeminizm, kultura popularna i konserwatywna modernizacja [w:] Kobiety w spoleczeństwie polskim, red. H. Szczodry, A. Pałęcka, M. Warat, Wydaunictuo Uniwersytetu Jagiellońskiego, Kraków 2011. 
Olivia Kłusek

Nowak S., Bądź Cosmo! Kolorowa prasa kobieca, popkultura i seksualność, https://www. academia.edu/1928882/\%C4\%85\%C5\%BA_Cosmo_Kolorowa_prasa_kobieca_popkultura_ i_seksualno\%C5\%9B\%C4\%87 [dostęp: 20.06.2016].

Stukonis M., Od Redaktora, http://www.elle.pl/magazyn/2015-elle-3 [dostęp: 1.11.2016].

Ślęczka K., Rola kobiet we wspótczesnych transformacjach społecznych - w zwierciadle feminizmu [w:] Kobiety wobec przemian okresu transformacji, red. K. Faliszek, E. McLean Petras, K. Wódz, Katowice 1997. 